\title{
PELATIHAN DETEKSI DINI MENCEGAH TERJADINYA STROKE PADA LANSIA PIMPINAN RANTING 'AISYIYAH ALUN-ALUN UTARA KOTAGEDE YOGYAKARTA
}

\author{
${ }^{1)}$ Lailatuz Zaidah ${ }^{2)}$ Dika Rizki Imania \\ 1,2,)Program Studi Fisioterapi S1, Fakultas Ilmu Kesehatan, Universitas Aisyiyah Yogyakarta \\ 1,2,) Jln.Siliwangi No 63 Ringroad Barat Mlangi, Nogotirto, Gamping Sleman Yogyakarta \\ E-mail : Lailatuzzaidah@unisayogya.ac.id,Dikarizki@unisayogya.ac.id
}

\begin{abstract}
ABSTRAK
Latar belakang :Stroke adalah gejala-gejala defisitfungsi saraf yang diakibatkan oleh penyakit pembuluh darah otak, bukan oleh sebab yang lain (WHO). Gangguan fungsi syaraf pada stroke disebabkan oleh gangguan peredaran darah otak non traumatik. Gangguan syaraf tersebut menimbulkan gejala antara lain: kelumpuhan wajah atau anggota badan, bicara tidak lancar, bicara tidak jelas (pelo), perubahan kesadaran, gangguan penglihatan, dan lain-lain. Stroke merupakan penyebab disabilitas nomor satu dan penyebab kematian nomor dua di dunia setelah penyakit jantung iskemik baik di negara maju maupun berkembang. Metode : pelatihan ini dilakukan dengan metode ceramah dan apllikasi kepada kader dan lansia di PRA Alun-alun Utara kotagede Tujuan: Bertambahnya pengetahuan kader posyandu dan ibu 'Aisyiyah Alun-Alun Utara tentang gangguan pembuluh darah otak, tentang deteksi dini terjadinya stroke serta pelatihan dalam mencegah terjadinya stroke. Hasil para Kader lansia mampu melakukan cara bagaimana deteksi dini stroke dengan melakukan pengukuran tensi darah serta mampu mengetahui batas normal dari nilai kadar kolesterol dan gula darah, Rekomendasi kegiatan ini bisa dilakukan secara rutin dengan diadakannya posyandu lansia
\end{abstract}

Kata Kunci: Stroke, Deteksi Dini stroke, pencegahan stroke

\section{ABSTRACT}

Background: Stroke is a symptom of nerve deficit function caused by cerebral vascular disease, not by other causes (WHO). Nerve function disorders in stroke are caused by non-traumatic brain circulatory disorders. This nerve disorder causes symptoms, including: paralysis of the face or limbs, speech is not fluent, speech is not clear (pelo), Stroke is the number one cause of disability and the number two cause of death in the world after ischemic heart disease in both developed and developing countries. Methods: This training was conducted by lecturing and applying to cadres and the elderly at PRA Alun-alun Utara, Kotagede. Objectives: Increasing the knowledge of posyandu cadres and 'Aisyiyah Alun-Alun Utara' about brain blood vessel disorders, early detection of stroke and training in preventing the occurrence of a stroke. The results of the elderly cadres are able to do how to detect stroke early by measuring blood pressure and being able to know the normal limit of the value of cholesterol and blood sugar levels. Recommendations for this activity can be done regularly by holding posyandu for the elderly Keywords: Stroke, Stroke Early Detection, Stroke Prevention

\section{PENDAHULUAN}

\section{Analisi Situasi}

Tantangan besar yang dihadapi bangsa Indonesia saat ini adalah masalah kesehatan. Tiga masalah kesehatan penting diantaranya bertambahnya penyakit tidak menular, penyakit infeksi dan kemunculan penyakit yang seharusnya sudah berhasil diatasi. Untuk mengatasi masalah kesehatan tersebut diperlukan tindakan preventif yang bertujuan meningkatkan kualitas hidup bangsa. Hal ini tertuang dalam Instruksi Presiden yang menjadi salah satu bagian arti Germas yaitu cek kesehatan secara rutin yang bermanfaat untuk memudahkan deteksi penyakit atau masalah kesehatan lebih dini. Cek kesehatan secara ideal dilakukan secara berkala untuk mengetahui kondisi kesehatan terkini sehingga bisa mendeteksi penyakit dan bisa mencegahnya. [1].

Cek kesehatan secara rutin dapat mengurangi resiko penyebab kematian. Kurangnya perhatian individu dalam urusan kesehatan menjadi ancaman global bagi pertumbuhan ekonomi karena dapat menurunkan produktivitas sumber daya manusia. PTM sulit disembuhkan total apabila penyakit sudah sampai tahap akhir dan membutuhkan biaya pengobatan yang tinggi 
Berdasarkan Hasil Riskesdas 2018 menunjukkan bahwa terjadi peningkatan kejadian Penyakit Tidak Menular (PTM) dalam 5 tahun terakhir. Prevalensi stroke naik dari 7 persen menjadi 10,9 persen, angka kejadian kanker naik dari 1,4 persen menjadi 1,8 persen, dan penyakit ginjal kronik naik dari 2 persen menjadi 3,8 persen. Sementara berdasarkan pemeriksaan tekanan dan gula darah, diabetes melitus naik dari 6,9 persen menjadi 8,5 persen, dan kasus hipertensi meningkat dari 25,8 persen menjadi 34,1 persen.

Stroke adalah gejala-gejala defisit fungsi saraf yang diakibatkan oleh penyakit pembuluh darah otak, bukan oleh sebab yang lain (WHO). Gangguan fungsi syaraf pada stroke disebabkan oleh gangguan peredaran darah otak non traumatik.Gangguan syaraf tersebut menimbulkan gejala antara lain: kelumpuhan wajah atau anggota badan, bicara tidak lancar, bicara tidak jelas (pelo), perubahan kesadaran, gangguan penglihatan, dan lain-lain. Stroke merupakan penyebab disabilitas nomor satu dan penyebab kematian nomor dua di dunia setelah penyakit jantung iskemik baik di negara maju maupun berkembang. Stroke dapat mengakibatkan kematian atau kecacatan yang akan menurunkan status kesehatan dan kualitas hidup penderita stroke, di samping itu akan menambah beban biaya kesehatan yang ditanggung keluarga dan negara.[9]

PTM seringkali muncul diam-diam tanpa tanda dan gejala, namun tetap menyimpan potensi bahaya yang luar biasa. PTM pada dasarnya dapat dideteksi secara dini apabila individu peka terhadap perubahan tubuh yang memberikan sinyal sebelum manifestasi berupa tanda dan gejala, sehingga tingkat keparahan penyakit dapat dicegah. Cara yang dilakukan untuk menangkap sinyal tersebut adalah dengan melakukan cek kesehatan secara rutin. Pemeriksaan yang dilakukan terbagi menjadi 2 yaitu pemeriksaan laboratorium (pemeriksaan darah, kadar gula darah, kadar lemak, fungsi ginjal, fungsi hati, dan elektrolit) dan pemeriksaan fisik (cek EKG untuk jantung, pemeriksaan fungsi dan kesehatan paru-paru). [2]

Semakin dini suatu penyakit terdeteksi, maka semakin cepat pertolongan yang dapat diberikan. Dengan begini, penyakit tidak berlanjut ke tahap yang lebih serius, sekaligus mencegah pertolongan yang lebih rumit. Masyarakat Purbayan merupakan masyarakat yang padat penduduk dari jumlah populasi anak-anak, dewasa dan Lansia, di alun-alun utara kotagede kelompok lansia memiliki posyandu yang dikoordinir dari perangkat kampung baik RT maupun $\mathrm{RW}$, tingkat kesehatan lansia di pimpinan ranting aisyiyah alun-alun utara cukup bagus, karena mereka rutin untuk konsultasi dengan tim medis, sekitar $10 \%$ jumlah penduduk terkena stroke, karena kurangnya pengetahuan resiko kejadian stroke

\section{METODE PELAKSANAAN}

\section{Metode Pelaksanaan Kegiatan}

Metode Pelaksanaan kegiatan menjelaskan solusi yang ditawarkan untuk mengatasi permasalahan yang dihadapi yaitu dengan memaparkan mengenai Stroke dan kesehatan tubuhl, dan melakukan Deteksi Dini mencegah terjadinya stroke. Kegiatan yang dilakukan adalah :

1. Bekerjasama dengan pihak Posyandu dan ibu 'Aisyiyah Alun-Alun Utara kotagede untuk mengadakan pertemuan. Hal ini bertujuan untuk sosialisasi, perkenalan, publikasi, serta menyepakati jadwal kegiatan yang akan dilakukan.

2. Melakukan edukasi perkembangan dengan penyuluhan dan diskusi tanya jawab kepada kader posyandu dan ibu 'Aisyiyah mengenai kesehatan pembuluh darah diotak, serta deteksi dini mencegah terjadinya stroke. Kegiatan ini bertujuan untuk menambah pengetahuan kader yang juga sebagai keluarga yang mendukung kesehatan serta bisa memberikan solusi untuk mengatasi terjadinya penyakit tidak menular. Kader, diharapkan selanjutnya bisa menjelaskan kepada ibu-ibu yang lain. 


\section{Kerangka Kerja Pengabdian}

Untuk mempermudah dalam kegiatan pengabdian ini, maka penulis membuatkan kerangka kerja

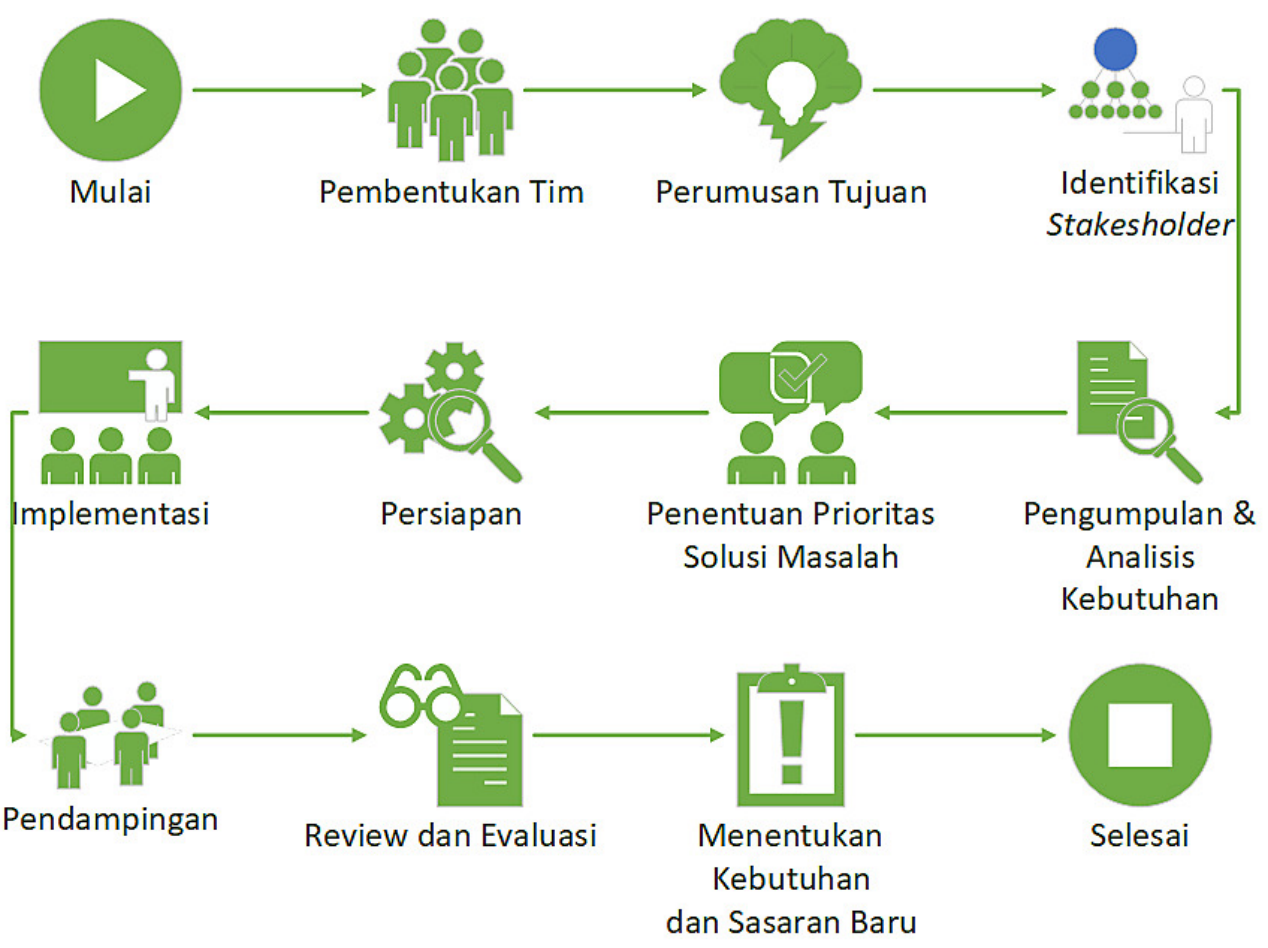

Gambar 1. Kerangka Kerja Kegiatan Pengabdian

Pada tahap ini dilakukan beberapa kegiatan sebagai berikut (bekerjasama dengan kader posyandu dan ibu 'Aisyiyah Ranting Alun-Alun Utara kotagede yogyakarta).

1. Melakukan survey wilayah dan sasaran kegiatan

2. Melakukan perijinan dengan pihak posyandu, ibu 'Aisyiyah ranting alun-alun utara kotagede dan pejabat yang berwenang.

3. Melakukan sosialisasi dengan pihak posyandu dan ibu 'Aisyiyah Yogyakarta terkait rencana kegiatan

4. Melakukan persiapan media edukasi tentang kesehatan pembuluh darah otak dan tentang stroke

5. Melakukan persiapan alat untuk mendukung jalannya kegiatan

6. Melakukan publikasi kepada sasaran kegiatan

\section{HASIL}

\begin{tabular}{ccllll}
\hline No & Waktu & \multicolumn{2}{c}{ Bentuk Kegiatan } & \multicolumn{2}{c}{ Pelaksanaan } \\
\hline 1. & 10 Desember 2019 & $\begin{array}{l}\text { Pembagian tugas tim dan } \\
\text { merancang isi kegiatan }\end{array}$ & $\begin{array}{l}\text { Pengabdi } \\
\text { mahasiswa }\end{array}$ & dan \\
\hline 2. & 10 Januari 2020 & $\begin{array}{l}\text { Sosialisasi dan penyuluhan } \\
\text { tentang }\end{array}$ & $\begin{array}{l}\text { Pengabdi } \\
\text { Stroke,bahaya } \\
\text { mahasiswa }\end{array}$ & dan \\
& & $\begin{array}{l}\text { Stroke, dan deteksi dini } \\
\text { stroke serta pencegahannya }\end{array}$ & \\
\hline 3. & 10 Februari 2020 & Koordinasi & Tim untuk & Pengabdi & dan \\
& & persiapan & memberikan & mahasiswa & \\
\hline
\end{tabular}




\begin{tabular}{|c|c|c|c|c|}
\hline & & $\begin{array}{l}\text { pelatihan Bagaimana cara } \\
\text { mendeteksi dini terjadinya } \\
\text { stroke, dengan cara pelatihan } \\
\text { melakukan tes tekanan darah } \\
\text { secara digital }\end{array}$ & & \\
\hline 4. & 10 Maret 2020 & $\begin{array}{l}\text { Memberikan pelatihan } \\
\text { pengecekan kolesterol, dan } \\
\text { Kadar gula darah dengan } \\
\text { memberikan pengetahuan } \\
\text { tentang nilai normal dalam } \\
\text { masing-masing tes }\end{array}$ & $\begin{array}{l}\text { Pengabdi } \\
\text { mahasiswa }\end{array}$ & dan \\
\hline 5. & 15 Juni 2020 & $\begin{array}{l}\text { Koordinasi TIM untuk } \\
\text { persiapan memberikan } \\
\text { pelatihan deteksi dini stroke } \\
\text { dan juga memberikan edukasi } \\
\text { tentang pencegahan dalam } \\
\text { melawan virus covid-19 } \\
\end{array}$ & $\begin{array}{l}\text { Pengabdi } \\
\text { mahasiswa }\end{array}$ & dan \\
\hline 6. & 18 Juli 2020 & $\begin{array}{l}\text { Melakukan pendampingan } \\
\text { pada ibu-ibu kader dengan } \\
\text { melakukan pre test dalam } \\
\text { pemahaman tentang deteksi } \\
\text { dini stroke }\end{array}$ & $\begin{array}{l}\text { Pengabdi } \\
\text { mahasiswa }\end{array}$ & dan \\
\hline
\end{tabular}

\section{Dokumentasi Kegiatan}
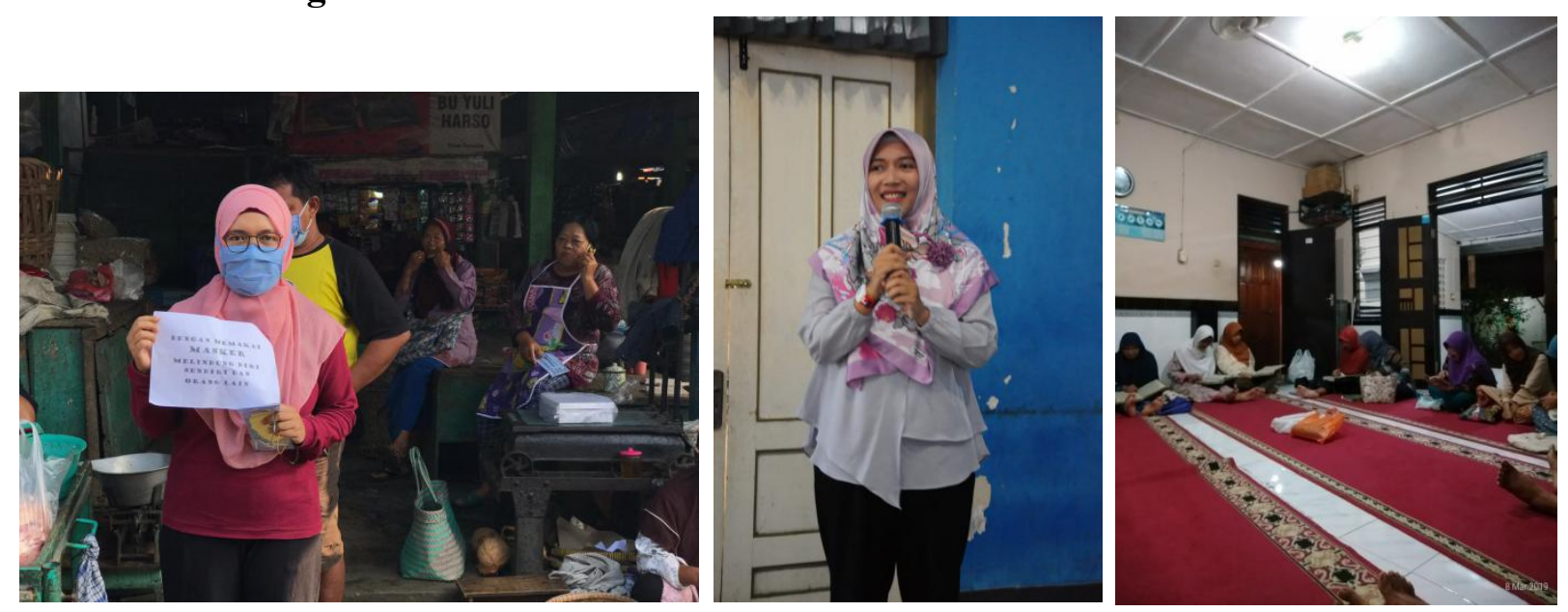

Gambar 2. Kegiatan penyampaian materi

Pada dokumentasi ini adalah sebagai penyampaian materi dalam pelaksanaan pengabdian masyarakat, pada saat pagi hari di lingkungan PRA Alun-Alun Utara, dengan ditambahi sosialisasi pentingnya protokol kesehatan dalm kegiatan sehari-hari selama pandemi Covid-a9 saat ini, dan pada malam hari dilakukan sosialisasi penyampaian materi di ibu-ibu pengajian PRA Aisyiyah ALun-ALun Utara 


\section{Tabel pengolahan data}

Tabel 1. Tabel Pengolahan Data

\begin{tabular}{|c|c|c|c|c|c|}
\hline No & Nama & usia & alamat & tensi & ket \\
\hline 1 & $\mathrm{Bu}$ sustiani & 50 tahun & Kagen raya & $130 / 90$ & hadir \\
\hline 2 & $\mathrm{Bu}$ maniah & 53 tahun & Kagen raya & $110 / 80$ & hadir \\
\hline 3 & $\begin{array}{l}\mathrm{Bu} \text { herti } \\
\text { harjoko }\end{array}$ & 52 tahun & $\begin{array}{ll}\text { Gang } & \text { tim } \\
\text { tim } & \end{array}$ & $120 / 90$ & hadir \\
\hline 4 & $\begin{array}{l}\mathrm{Bu} \text { savitri } \\
\text { ningsih }\end{array}$ & 55 tahun & $\begin{array}{l}\text { Gang } \\
\text { purbayan }\end{array}$ & $130 / 80$ & hadir \\
\hline 5 & $\begin{array}{l}\mathrm{Bu} \quad \text { popi } \\
\text { erlis }\end{array}$ & 60 tahun & $\begin{array}{l}\text { Gang } \\
\text { sulawesi }\end{array}$ & $120 / 80$ & hadir \\
\hline 6 & $\begin{array}{ll}\mathrm{Bu} & \text { siti } \\
\text { rahmah } & \end{array}$ & 58 tahun & samakan & $140 / 80$ & hadir \\
\hline 7 & $\begin{array}{l}\mathrm{Bu} \text { fitri } \\
\text { martanti }\end{array}$ & 50 tahun & $\begin{array}{ll}\text { Gang gito } \\
\text { gati }\end{array}$ & $130 / 90$ & hadir \\
\hline 8 & Bu endang & 55 tahun & $\begin{array}{l}\text { Gang } \\
\text { narayana }\end{array}$ & $140 / 80$ & hadir \\
\hline 9 & Bu nunuk & 59 tahun & $\begin{array}{l}\text { Gang } \\
\text { arjuno }\end{array}$ & $130 / 80$ & hadir \\
\hline 10 & $\begin{array}{l}\mathrm{Bp} \\
\text { misdiyanto }\end{array}$ & 61 tahun & $\begin{array}{l}\text { Gang } \\
\text { kalimanta }\end{array}$ & $120 / 90$ & hadir \\
\hline 11 & $\begin{array}{l}\text { Bp. } \\
\text { margono }\end{array}$ & 60 tahun & $\begin{array}{l}\text { Gang } \\
\text { arjuno }\end{array}$ & $130 / 90$ & hadir \\
\hline 12 & $\begin{array}{l}\mathrm{Bp} \\
\text { subiyono }\end{array}$ & 58 tahun & $\begin{array}{l}\text { Gang } \\
\text { sulawesi }\end{array}$ & $110 / 80$ & hadir \\
\hline 13. & Bu satilah & 54 tahun & $\begin{array}{l}\text { Gang } \\
\text { purbayan }\end{array}$ & $120 / 90$ & hadir \\
\hline 14. & $\begin{array}{ll}\mathrm{Bu} & \text { siti } \\
\text { fauziah } & \end{array}$ & 55 tahun & $\begin{array}{l}\text { Gang } \\
\text { samakan }\end{array}$ & $130 / 80$ & hadir \\
\hline 15. & $\mathrm{Bu}$ jumiati & 56 tahun & Kawen raya & $120 / 80$ & hadir \\
\hline 16 & $\mathrm{Bu}$ endah & 62 tahun & Kagen raya & $140 / 80$ & hadir \\
\hline 17. & Bu supriati & 60 tahun & $\begin{array}{l}\text { Gang } \\
\text { timtim }\end{array}$ & $130 / 90$ & hadir \\
\hline 18. & Bp ramdani & 59 tahun & Gang bali & $140 / 80$ & hadir \\
\hline 19. & Bu surtini & 60 tahun & $\begin{array}{l}\text { Gang } \\
\text { kalimantan }\end{array}$ & $130 / 80$ & hadir \\
\hline 20 & Bp wijilan & 61 tahun & $\begin{array}{l}\text { Gang } \\
\text { noroyono }\end{array}$ & $120 / 90$ & hadir \\
\hline
\end{tabular}




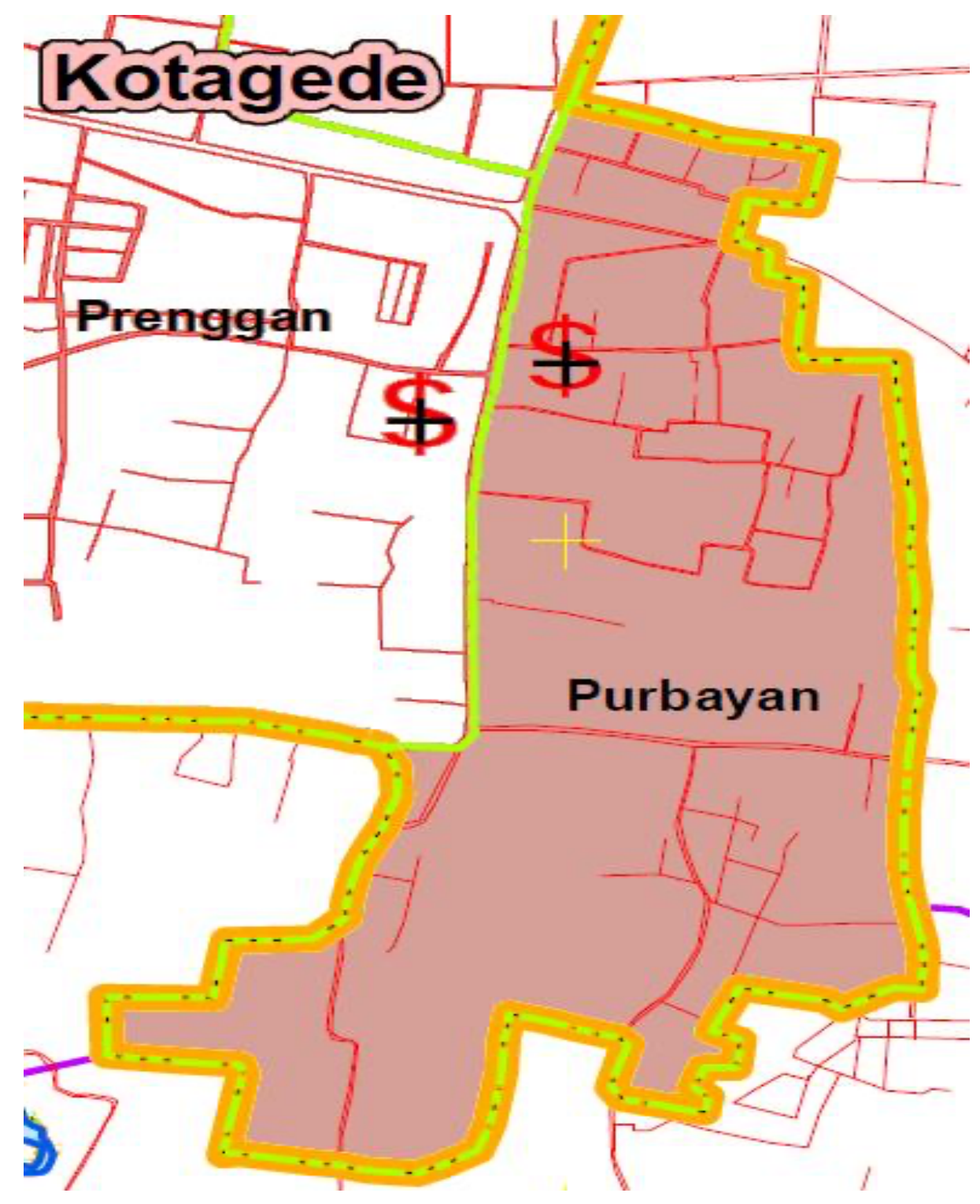

Gambar 3. Lokasi kegiatan

Kotagede merupakan kecamatan dikota yogyakarta, Povinsi Daerah Istimewa Yogyakarta. Kotagede adalah sebuah kota lama yang terletak di Yogyakarta bagian selatan yang secara administratif terletak di kota Yogyakarta dan Kabupaten Bantul. Sebagai kota kuno bekas ibukota Kerajaan Mataram Islam yang berdiri pada tahun 1532 M. Kotagede memiliki 3 kelurahan diantaranya adalah : prenggan, rejowinangun dan purbayan. Jumlah penduduk purbayan berjumlah sebanyak 10.010 penduduk.

\section{KESIMPULAN}

Kesimpulan dari kegiatan pengabdian masyarakat yang di laksanakan ini masyarakat lebih tau dan memahami tentang pentingnya menjaga kesehatan terhadap penyakit tidak menular terutama stroke ini, karena penyakit stroke merupakan penyakit yang bisa mengakibatkan kematian setelah penyakit jantung, sehingga masyarakat harus bisa mengenali tanda dan gejalanya serta mampu mendeteksi dini terhadap penyakit tersebut. 


\section{DAFTAR PUSTAKA}

[1] Achmanagara, A. 2012. Hubungan Faktor Internal Dan Eksternal Dengan Keseimbangan Lansia Di Desa Pamijen Sokaraja Banyumas. Tesis. Depok: UI

[2] Aji, W. P. M. 2015. Pengaruh Senam Lansia terhadap Tekanan Darah pada Lansia Penderita Hipertensi di Posyandu Lansia Dusun Banaran 8 Playen Gunung Kidul. [Naskah Publikasi Ilmiah]. Yogyakarta: Sekolah Tinggi Ilmu Kesehatan 'Aisyiyah Yogyakarta.

[3] Bandiyah, Siti. 2009. Lanjut Usia dan Keperawatan Gerontik. Yogyakarta: Nuha Medika

[4] Batson, Glenna. 2008. "Proprioception", International Association for Dance Medicine and Science. https://www.iadms.org/page/210. Diakses pada tanggal 30 Oktober 2016.

[5] Cetin, N. Bayramoglu, M. Aytar, A. Surenko, D. Yemisci, U.O. 2008. Effects of LowerExtremity and Trunk Muscle Fatigue on Balance The Open Sports Medicine Journal, 2008, 2: 16-22.

[6] Cho, S.I. A,, DH. 2014. Effects of a Fall Prevention Exercise Program on Muscle Strength and Balance of the Old-old Elderly. J. Phys. T 1772 her. Sci. Vol. 26, No. 11, 2014

[7] Dahlan S. 2008. Statistik Untuk Kedokteran dan Kesehatan. Jakarta: Salemba Medika.

[8] Greve J.. Alonso A,.Ana., Bordini P.G and Camanho, L.G. 2007. "Correlation Between Body Mass Index And Postural Balance”. Clinics 2007;62(6):717-20.

[9] Guccione, A. Wong, R. Avers, D. 2012. Geriatric Physical Therapy, 3rd Edition. ISBN: 9780-323-02948-3.

[10] Highstein , M.S. Holstein, R.G. 2012. The Anatomical and Physiological Framework for Vestibular Prostheses. 2012 November ; 295(11)

[11]Howe, T,E. Rochester, L. Jackson, A. Banks, P,M,H and Blair, V, A. 2008. Exercise for improving balance in older people. Glasgow: John Wiley \& Sons.

[12] Irfan, M. 2010. “Fisioterapi Bagi Insane Stroke”, Graha Ilmu, Yogyakarta, 2010. 